ARTIGO

\title{
Relações Brasil-Argentina: uma análise dos avanços e recuos
}

ALESSANDRO WARLEY CANDEAS*

Rev. Bras. Polit. Int. 48 (1): 178-213 [2005]

\section{Introdução}

Nada há de original em afirmar que as relações Brasil-Argentina foram erráticas durante grande parte da História. A real dimensão das convergências e divergências é, contudo, menos evidente. Neste artigo se tenta examinar os avanços e recuos da relação bilateral, conforme esquematizado no gráfico a seguir.

A diplomacia argentina responde historicamente a impulsos contraditórios de dependência e autonomia, isolacionismo e protagonismo. Entretanto, como nota Juan Carlos Puig, por trás dessa "incongruência epidérmica" há uma "coerência estrutural."

Neste artigo se indaga a existência de "coerência estrutural" por trás das "incongruências epidérmicas" da política argentina em relação ao Brasil. Essa questão suscita duas outras:

1. o relacionamento com o Brasil é determinado pela estratégia de inserção global ou regional da Argentina?

2. a política interna argentina influencia sua postura em relação ao Brasil?

\footnotetext{
* Diplomata de carreira. As opiniōes expressas neste artigo são estritamente pessoais (alessandro. candeas@mec.gov.br).

${ }^{1}$ PUIG, Juan Carlos. La política exterior argentina: incongruencia epidérmica y coherencia estructural. In: PUIG, Juan Carlos (comp.). América Latina: politicas exteriores comparadas.
} 
As aproximações entre Argentina e Brasil ocorreram até os anos 70 de forma irregular - perpassando regimes tão diversos como os de Urquiza, Mitre, Roca, Sáenz Peña, Justo, Perón e Frondizi - e se intensificaram desde os anos 80 - passando igualmente por governos tão díspares como os de Videla, Alfonsín, Menem, Duhalde e Kirchner. Essa constatação sugere que a natureza do relacionamento com o Brasil passou de conjuntural a estrutural, independentemente do regime político (ditadura, democracia) ou da situação econômica (inflação, crise, estabilidade, crescimento). Por outro lado, é evidente que o aprofundamento da democracia e do desenvolvimento econômico fortalece estruturalmente a relação bilateral, no sentido de maior integração.

A história dos laços bilaterais revela que as relações se iniciam sob o signo da instabilidade estrutural no século XIX e avançam rumo à estabilidade estrutural pela integração no século XXI. As fases intermediárias foram instabilidade conjuntural e busca de cooperação (1898-1961), instabilidade conjuntural com rivalidade (1962-1979) e construção da estabilidade estrutural pela cooperação (1979-1987) e pela integração (desde 1988).

Nessa perspectiva, a resposta à questão central seria que a construção da estabilidade constitui a "coerência estrutural" ou fio condutor do relacionamento Brasil-Argentina.

No quadro seguinte se tenta responder à questão sobre se o relacionamento bilateral é determinado pela estratégia de inserção global e regional da Argentina.

A comparação entre as colunas mostra que não há correspondência necessária entre as estratégias global e regional da Argentina e os laços com o Brasil. Por conseguinte, a relação com o Brasil pertence a uma categoria autônoma, condicionada, mas não determinada, pelas estratégias de inserção externa geral ou regional da Argentina.

A relação bilateral não se infere a partir de terceiros porque tem uma dinâmica própria, que resulta da crescente interdependência entre os dois países e responde aos desequilíbrios de poder relativo. Constatado esse desequilíbrio, abrem-se historicamente dois caminhos: a busca do reequilíbrio ou da contenção (jogo de soma zero) ou a construção de poder compartilhado diante do mundo (jogo de soma positiva).

Quanto à influência que têm fatores internos na postura em relação ao Brasil, os laços bilaterais são fortemente condicionados pelas 


\begin{tabular}{|c|c|c|c|}
\hline Períodos & $\begin{array}{c}\text { Relações Argentina- } \\
\text { Brasil }\end{array}$ & $\begin{array}{c}\text { Estratégia de inserção global } \\
\text { da Argentina }\end{array}$ & $\begin{array}{c}\text { Relações Argentina-América } \\
\text { Latina }\end{array}$ \\
\hline 1810-1898 & $\begin{array}{l}\text { Instabilidade estrutural } \\
\text { com predomínio da } \\
\text { rivalidade }\end{array}$ & $\begin{array}{l}\text { Dependência em relação à } \\
\text { Grã-Bretanha, europeísmo e } \\
\text { enfrentamento com os EUA }\end{array}$ & $\begin{array}{c}\text { Isolacionismo e não- } \\
\text { ingerência. Apesar disso, } \\
\text { intervenções no Uruguai e } \\
\text { Guerra do Paraguai }\end{array}$ \\
\hline 1898-1914 & \multirow{4}{*}{$\begin{array}{l}\text { Instabilidade } \\
\text { conjuntural e busca de } \\
\text { cooperação, com } \\
\text { momentos de } \\
\text { rivalidade }\end{array}$} & & \\
\hline 1914-1945 & & $\begin{array}{c}\text { Neutralidade nas Guerras } \\
\text { Mundiais. Tentativa de } \\
\text { manutenção de dependência } \\
\text { da Grã-Bretanha e atritos com } \\
\text { os EUA }\end{array}$ & \multirow[t]{2}{*}{$\begin{array}{l}\text { Protagonismo diplomático e } \\
\text { mediação na Guerra do } \\
\text { Chaco. Busca de integração } \\
\text { comercial. Tentativa de } \\
\text { "exportação" do peronismo }\end{array}$} \\
\hline 1946-1955 & & $\begin{array}{l}\text { Terceira posição: autonomia } \\
\text { heterodoxa em relação aos } \\
\text { EUA e universalização de } \\
\text { contatos diplomáticos e } \\
\text { comerciais }\end{array}$ & \\
\hline 1955-1961 & & \multirow{2}{*}{$\begin{array}{c}\text { Alinhamento aos EUA, embora } \\
\text { com busca de espaços de } \\
\text { autonomia }\end{array}$} & \multirow{3}{*}{$\begin{array}{c}\text { Busca de solução de litígios } \\
\text { territoriais e de } \\
\text { interdependência econômica. } \\
\text { Ambigüidade na questão } \\
\text { cubana }\end{array}$} \\
\hline 1962-1973 & \multirow{3}{*}{$\begin{array}{l}\text { Instabilidade } \\
\text { conjuntural com } \\
\text { predomínio da } \\
\text { rivalidade }\end{array}$} & & \\
\hline 1973-1976 & & $\begin{array}{l}\text { Tentativa de reedição da } \\
\text { autonomia heterodoxa }\end{array}$ & \\
\hline 1976-1979 & & \multirow{2}{*}{$\begin{array}{l}\text { Oscilação entre autonomia } \\
\text { heterodoxa e alinhamento aos } \\
\text { EUA. Guerra das Malvinas }\end{array}$} & \multirow{2}{*}{$\begin{array}{c}\text { Hostilidade em relação ao } \\
\text { Chile e combate à "infiltração } \\
\text { comunista" }\end{array}$} \\
\hline 1979-1983 & \multirow{2}{*}{$\begin{array}{l}\text { Construção da } \\
\text { estabilidade estrutural } \\
\text { pela cooperação }\end{array}$} & & \\
\hline 1983-1988 & & \multirow{2}{*}{$\begin{array}{l}\text { Persistência do modelo } \\
\text { heterodoxo com ênfase no } \\
\text { Mundo Não-Alinhado }\end{array}$} & \multirow{2}{*}{$\begin{array}{l}\text { Referência para a } \\
\text { redemocratização e impulso à } \\
\text { interdependência econômica }\end{array}$} \\
\hline 1988-1989 & \multirow{3}{*}{$\begin{array}{l}\text { Construção da } \\
\text { estabilidade estrutural } \\
\text { pela integração }\end{array}$} & & \\
\hline 1989-2001 & & $\begin{array}{l}\text { Alinhamento aos EUA. } \\
\text { Não-proliferação e busca de } \\
\text { protagonismo estratégico } \\
\text { global }\end{array}$ & $\begin{array}{l}\text { Fundador do Mercosul. } \\
\text { Tenta representar interesses } \\
\text { estratégicos dos EUA }\end{array}$ \\
\hline Desde 2002 & & $\begin{array}{c}\text { Atualização da autonomia } \\
\text { heterodoxa }\end{array}$ & $\begin{array}{c}\text { Integração. } \\
\text { Aproximação com Venezuela e } \\
\text { arestas com Chile }\end{array}$ \\
\hline
\end{tabular}

disputas entre modelos alternativos de desenvolvimento argentino e sua correspondente distribuição de poder entre atores que lutam por distintos projetos de país.

Em síntese, de um lado, múltiplos fatores intervêm nas relações Brasil-Argentina, nenhum dos quais sendo determinante de forma 
isolada: geografia, rivalidade estratégica, economia, burocracias de Estado, política interna (disputa entre modelos de desenvolvimento). O impacto diferenciado desses fatores em distintos momentos da história explica a "incongruência epidérmica” dos laços bilaterais.

De outro lado, há fatores recentes que constróem uma "coerência estrutural" baseada na estabilidade e na integração: superação de desconfianças, intercâmbio cultural e turismo (que gera maior conhecimento recíproco e simpatia), cadeias produtivas, estratégias conjuntas de exportação e negociação multilateral, afinidades políticas. Fatores que conformam uma "sociedade estratégica" 2 , que vai além da "aliança estratégica”, e viabilizam a construção de poder compartilhado.

\section{Momento: instabilidade estrutural com predomínio da rivalidade (1810-1898)}

\section{Os processos de Independência}

A independência argentina se concretizou em duas etapas. Disputavam poder partidários de projetos excludentes: os leais ao trono espanhol "usurpado" por José Bonaparte apostavam no retorno de Carlos IV; outros conspiravam em favor de um protetorado britânico; havia os que defendiam que Dona Carlota Joaquina, irmã de Fernando VII, reinasse no Prata; e os que lutavam pela independência.

O Cabildo de Buenos Aires proclamou, em 25 de maio de 1810, a ruptura com a Espanha ocupada. Durante a Restauração, Fernando VII, absolutista, recusou a proposta de governo constitucional apresentada por Rivadavia. Em resposta, o Congresso de Tucumán declara a Independência em 9 de julho de 1816.

A Argentina nasceu como projeto americanista - e nessa perspectiva lutou San Martín, libertando Chile, Bolívia e Peru -, antes que propriamente nacional: o Congresso de Tucumán proclamou a independência das "Provincias Unidas de Sudamérica", e não do "Río de la Plata”.

\footnotetext{
${ }^{2}$ RUSSELL, Roberto, e TOKATLIAN, Juan Gabriel, El lugar de Brasil en la politica exterior argentina, p. 16.
} 
Ao não romper com o sistema monárquico, contrastando com um hemisfério republicano, o Brasil foi percebido como herdeiro da aspiração hegemônica e intervencionista portuguesa no Prat. ${ }^{3}$

\section{Guerra contra o Império do Brasil}

Não há, na história brasileira, um capítulo "Guerra contra a República Argentina”. Na história argentina, contudo, figura uma "Guerra contra o Império do Brasil": o que conhecemos como "Guerra da Cisplatina”.

A historiografia argentina enfatiza um suposto "expansionismo imperial." ${ }^{4}$ Não é exagero afirmar que a alegada ameaça brasileira contribuiu para cimentar a unidade entre as províncias argentinas e a hegemonia da Província de Buenos Aires, que assume a condução das relaçōes externas da Confederação.

O conflito na Banda Oriental (1825-1828) é visto, no Brasil, como questão de honra para D. Pedro I, que se declara sucessor dos direitos de Portugal sobre a Província Cisplatina. A Argentina, apesar dos êxitos militares, sai derrotada econômica e politicamente. O Uruguai conquista sua independência, e a Inglaterra assegura a livre navegação do Prata.

A "perda" do Uruguai inaugura um dos mitos argentinos: o de nação "amputada" do território a que teria supostamente direito como sucessora do Vice-Reino do Prata. O papel do Brasil é evidentemente percebido como negativo, visto que sua ação iria subtrair da Argentina, além do Uruguai, o Paraguai e parte da região de Missóes. Os outros

\footnotetext{
${ }^{3}$ Entretanto, a monarquia era o sistema preferido por muitos próceres argentinos, que a consideravam mais adequada à tradição hispano-americana. Houve quem defendesse uma monarquia constitucional com um príncipe inglês ou francês ou um descendente de imperador Inca (para unificar todos os vice-reinos). FLORIA, Carlos Alberto e BELSUNCE, César A. García. Historia de los argentinos, p. 419 a 424.

4 "Rodríguez y Rivadavia temieron que [el Imperio] pretendiese avanzar hasta el Paraná o que se enfrentase con Buenos Aires, aprovechando en ambos casos la falta de unidad política de las províncias rioplatenses. Para ello, era menester que las provincias amenazadas constituyeran un bloque lo más sólido posible, capaz de resistir a los brasileños de toda tentación expansionista". Sobre D. Pedro II: "Su politica internacional sigue siendo ... de expansión territorial en América conforme al esquema heredado de Portugal'. FLORIA, Carlos Alberto e BELSUNCE, César A. García. Op. cit., p. 470 e 621 . Hoje, setores protecionistas argentinos apelam a esse temor ancestral de "invasão" de forma sublimada: invasão de produtos brasileiros.
} 
culpados pela "amputação" seriam Reino Unido (Malvinas), Chile (Terra do Fogo, Beagle e Puna de Atacama) e Bolívia (Alto Peru).

Puig critica severamente a "debilidade da política territorial" argentina ${ }^{5}$. A seu ver, o país não soube preservar sua "herança” em parte porque os territórios em litígio eram inóspitos e longínquos, inaptos para a exploração agrícola-ganadeira. Por conseguinte, conclui, as disputas territoriais se resolveram em detrimento da Argentina.

\section{O período Rosas}

A Argentina enfrentou o dilema entre governo central forte ou confederação. Os "unitários", liderados por Bernardino Rivadávia, defendiam a primazia de Buenos Aires e uma solução institucionalizada, com um ambicioso projeto "civilizador", liberal e progressista. Já os "federalistas", liderados por Juan Manuel Rosas, pragmático, autoritário e nacionalista, rejeitavam a hegemonia portenha e preferiam um sistema de simples pactos políticos entre províncias.

O acordo que pôs fim à "Guerra contra o Brasil” obriga Rivadavia a renunciar e abre caminho para o período Rosas, eleito Governador de Buenos Aires em 1829. A era Rosas significou a consolidação do Estado nacional pelo sistema confederativo.

O novo centro dinâmico passariam a ser os portos do "Litoral", que recebiam fluxos de comércio, capitais, idéias e migrantes. A dualidade entre "civilização" urbana e europeizada e "barbárie" dos caudilhos do interior será sublinhada pelo presidente-escritor Domingo Sarmiento, que, ao lado de outros intelectuais europeizados e liberais - a "geração de $1837 "{ }^{6}$ - foram perseguido por Rosas.

Como encarregado dos Negócios Exteriores da Confederação Argentina, Rosas acentua o isolamento diplomático, recusando o comprometimento em esquemas associativos permanentes. As restrições à navegação criadas por Buenos Aires levaram França e Inglaterra a bloquear os portos da Confederação entre 1838 e 1848. A Argentina enfrentou de

\footnotetext{
${ }^{5}$ PUIG, Juan Carlos. Op. cit., p. 118 a 122.

${ }^{6}$ Formavam parte da "geração de 37" Esteban Echeverría, Miguel Cané e Juan Bautista Alberdi. Mais tarde se incorporariam, no exílio, Sarmiento e Bartolomé Mitre. Alberdi defendeu projeto de união aduaneira no Cone Sul, antecipando em um século e meio a idéia do Mercosul.
} 
forma heróica a pressão naval, obtendo acordos com aquelas potências no sentido de reconhecerem a jurisdição da Confederação sobre a navegação dos rios.

Fortalecido após a resistência ao bloqueio naval, Rosas alenta a idéia de superioridade militar contra o Império. Em reação, o Brasil passa a buscar a expulsão do líder argentino, usando como pretexto a questão cisplatina e explorando as forças centrífugas em Entre Ríos e Corrientes lideradas pelo general Urquiza. A aliança entre Brasil, províncias argentinas e colorados uruguaios derrota Rosas e abre caminho para a organização institucional da Argentina.

\section{Urquiza e Mitre. Transformações estruturais}

O presidente Urquiza (1854-1860) inicia profundas reformas estruturais, a começar pela Constituição de 1853, que se inspira nas teses de Alberdi - Bases y puntos de partida para la organización nacional. Restava pendente a questão do status de Buenos Aires, que rejeita o pacto federal e se constitui em Estado independente.

Urquiza instaura ambiente de distensão na Bacia do Prata, produzindo um salto qualitativo nas relações com o Brasil. Em 1856, firma com o Império o Tratado de Amizade, Comércio e Navegação. No ano seguinte, os dois países firmam tratado de limites - que não será ratificado pelo governo platino por problemas políticos internos.

Mitre (1862-1868) inaugura a primazia do liberalismo na política e na economia. Sua vitória sobre Urquiza na batalha de Pavón (1861) confirma a primazia da corrente liberal-nacional sobre a federalista e consolida o predomínio de Buenos Aires. Seu governo, avança nas reformas estruturais para a nova fase de desenvolvimento do país.

\section{A Guerra do Paraguai}

O Paraguai conformava uma pequena potência mediterrânea livre das pressões do capitalismo internacional, enclave de autonomia que incomodava argentinos, brasileiros e britânicos. A postura de neutralidade paraguaia seria alterada por Solano López, que pretendia mudar o equilíbrio de forças e buscar saída para o mar, com apoio dos blancos uruguaios. O Brasil intervém em apoio ao colorados. Contando com 
o apoio de Urquiza e da população de Entre Ríos e Corrientes, López invade Misiones rumo à Banda Oriental. Estavam dadas as condições para o Tratado secreto entre Brasil, Argentina e Uruguai, em 1865.

Por detrás da coincidência de objetivos - vencer Solano López e garantir a livre navegação -, Mitre temia o avanço territorial do Império em direção ao rio Paraná, apesar da convergência ideológica do liberalismo professado pelo presidente argentino e pelo gabinete brasileiro. Por outro lado, apesar do compromisso formal de respeito à integridade territorial do Paraguai, interpretaçōes divergentes sobre fronteiras animavam pretensões argentinas de anexação. Mercê dessas desconfianças, o Tratado da Tríplice Aliança estabelecia controles recíprocos entre os aliados, que não poderiam anexar o Paraguai, estabelecer protetorado ou negociar em separado até a deposição de López.

$\mathrm{Na}$ visão da Argentina, o Brasil tentaria reverter as condições vantajosas por ela inscritas no Tratado. $\mathrm{O}$ exército platino se desengajou militarmente do Paraguai à medida que rebeliōes provinciais obrigaram a deslocar tropas para o interior, o que conferiu ao Brasil preponderância militar no terreno. Terminado o conflito, a permanência de tropas brasileiras no Paraguai protegeu o governo guarani das pretensões territoriais argentinas. As tensões, que por pouco não geraram outra guerra entre Brasil e Argentina, são desanuviadas em 1876, quando Buenos Aires firma acordo de fronteiras com Assunção.

A presidência de Domingo Sarmiento (1868-1874) investe na modernização tanto no plano social, com um vasto programa de alfabetização e impulso à imigração européia, quanto no econômico expansão agropecuária e de ferrovias. O país inicia profunda transformação étnica e cultural. $\mathrm{O}$ sistema educativo visa a forjar uma nacionalidade comum, de língua hispânica, impedindo a desagregação cultural possivelmente causada pelo grande fluxo de imigrantes não-ibéricos.

Para a história Argentina, a Guerra do Paraguai constitui derrota diplomática e territorial. Apesar disso, o conflito deixou saldo positivo para a organização argentina, ao consolidar a formação do Estado a partir da hegemonia de Buenos Aires. Elemento central é a lei de federalização de Buenos Aires, de 1880, que passa a ser a capital federal. A consolidação institucional torna possível meio século de progresso ininterrupto em contexto de relativa estabilidade política e social. 


\section{La Generación del Ochenta}

Arrogancia, optimismo, creencia en la fatalidad del progreso, sensación de dominio de la situación y del porvenir. Ni los rumores de una posible crisis con Brasil inquietaban a la clase dirigente ${ }^{7}$. Assim se via a Argentina desde 1880, enraizando-se mitos fundadores como os de celeiro do mundo e terra próspera de acolhida de imigrantes em busca de liberdade. O Brasil era então visto com indiferença no plano econômico, como inferior nas esferas cultural e étnica e como rival estratégico. ${ }^{8}$

A Generación del Ochenta promoveu a construção ideológica da modernização argentina com base na transplantação cultural e étnica da Europa -inaugurando tensões permanentes com a identidade criolla ibérica, rural e tradicional. A sociedade se torna mais complexa, com o crescimento dos setores médios e urbanos da população. A elite, em ostentação e luxo - que atingirão seu ápice em Buenos Aires -, tinha Paris como segundo lar. ${ }^{9}$

As presidências de Julio Roca (1880-1886 e 1898-1904) foram momentos de estabilidade política e social que contribuíram para a consolidação territorial e a fixação das fronteiras. Ainda como ministro da Guerra, Roca havia conquistado forte popularidade com a "Campanha do Deserto", pela qual o país ampliou a fronteira agrícola e pecuária destruindo tribos indígenas da Patagônia.

A elite criolla resistiu a entregar parcelas de poder aos membros emergentes da sociedade (imigrantes, industriais, classe média). A União Cívica Radical (UCR) canalizou a reação aos métodos políticos espúrios da oligarquia tradicional.

As relaçóes com o Brasil melhoraram a partir do final do Império e início da República. Fundamental, para tanto, foi o entendimento sobre a região de Palmas/Missões. É significativo o fato de que esse contencioso fronteiriço escapa à regra de Puig (acima), segundo a qual a "debilidade da política territorial” argentina teria sido causada pela falta de interesse

\footnotetext{
${ }^{7}$ FLORIA, Carlos Alberto e BELSUNCE, César A. García. Op. cit., p. 673.

${ }^{8}$ RUSSELL, Roberto, e TOKATLIAN, Juan Gabrie. Op. cit., p. 14.

${ }^{9}$ Famílias abastadas, em viagens à Europa, levavam no barco não apenas seus funcionários domésticos, mas também galinhas e vacas.
} 
em lutar por áreas inaptas para a exploração agrícola-ganadeira. Ora, a controvérsia com o Brasil envolvia superfície de importante produção agropecuária. O laudo arbitral proferido pelo presidente Grover Cleveland em 1895 dá ganho de causa ao Brasil.

\section{Relação especial com o Reino Unido}

Julio A. Roca (filho) afirmava que "a Argentina, por sua interdependência recíproca, é, do ponto de vista econômico, parte integrante do Império Britânico". A relação privilegiada com o Reino Unido derivou da estratégia da elite de tirar maior proveito da situação periférica, convertendo o país em eficiente economia agroexportadora. Essa decisão implicou o abandono do esforço de poupança e industrialização e valorizou a cultura rentista.

A presença britânica era avassaladora no comércio, nos investimentos e empréstimos. No período de 1890 a 1914, a Argentina ocupou o primeiro lugar como destino de investimentos ingleses. A metáfora das "relações carnais" não é tão artificial: o complexo de produção, armazenamento, transporte e exportação de carne era praticamente monopolizado por empresas britânicas.

Se, por um lado, havia subordinação aos interesses comerciais britânicos, por outro, a Argentina tentou reagir aos métodos do capitalismo financeiro. A dependência da Grã-Bretanha conviveu com a resistência aos bloqueios navais e com controvérsias jurídico-diplomáticas. Dessa postura derivaram as "doutrinas" Irigoyen e Drago ${ }^{10}$. Ambas doutrinas sublinham valores constantes "grocianas" na política externa argentina: não-ingerência, autonomia nacional, igualdade de direitos entre Estados e busca de solução pacífica de controvérsias.

\footnotetext{
${ }^{10} \mathrm{O}$ chanceler Bernardo de Irigoyen reagiu à ameaça de canhoneira britânica - feita, aliás, por Manuel Quintana (futuro presidente) - para forçar a soltura do gerente do Banco de Londres, em 1876. Já o chanceler José Maria Drago condenou em 1902 o uso da força por motivos financeiros empregado contra a Venezuela por navios de Grã-Bretanha, Alemanha e Itália. Temia-se que a Grã-Bretanha adotasse medida semelhante com a Argentina. O Brasil não apoiou a Doutrina Drago, em parte por entender que não estava em causa a Doutrina Monroe (rejeitada pela Argentina), e em parte para não favorecer a liderança do país vizinho.
} 


\section{América Latina e Estados Unidos}

As iniciativas de solidariedade americana, ademais de terem tendência antieuropéia, eram inoperantes nas questões estratégicas de interesse argentino (Malvinas, bloqueios navais).

$\mathrm{O}$ antiamericanismo está presente na mentalidade argentina desde o ataque às Malvinas que precedeu a ocupação britânica. A elite da Generación del Ochenta havia feito opção preferencial pela Europa e desprezava os Estados Unidos. Ao contrário do Brasil, o intercâmbio comercial com aquele país era pouco expressivo, tanto pelo perfil semelhante da produção agropecuária quanto pelo desvio comercial forçado pelo protecionismo norte-americano.

A Argentina boicotou a Primeira Conferência Panamericana (1889-1890). Na ocasião, confrontando a doutrina Monroe, o chefe da Delegação argentina, chanceler Roque Sáenz Peña, proclama a "América para a humanidade". A oposição argentina inviabilizou o projeto de união aduaneira continental, abortando o embrião da Alca.

\section{Momento: instabilidade conjuntural e busca de cooperação com momentos de rivalidade (1898-196I)}

\section{De Roca à Argentina do centenário}

O presidente Julio A. Roca firma o Tratado de Fronteira com o Brasil em 1898, abrindo período inédito de aproximação bilateral. Realiza-se a primeira troca de visitas presidenciais - Roca visita o Brasil em 1899 e Campos Sales, a Argentina, em 1900.

O presidente Roque Sáenz Peña (1910-1914) atua de forma cautelosa para evitar o acirramento de tensões com o Brasil: visita o Brasil em 1910, ocasião em que pronuncia a célebre frase "tudo nos une, nada nos separa”. A percepção argentina era de que o chanceler Rio Branco imprimia mudanças significativas em relação à diplomacia do início da República, no sentido de restaurar a preeminência na América do Sul, coerente com as "tradições imperiais". ${ }^{11}$

${ }^{11}$ CERVO, Amado Luiz e BUENO, Clodoaldo. História da Política Exterior do Brasil, p. 176. 
As desconfianças eram particularmente motivadas pela reorganização naval do Brasil, que refletiria a aproximação com os Estados Unidos no âmbito de um suposto pacto pelo qual o Brasil exerceria a hegemonia sul-americana, como co-garante da doutrina Monroe. ${ }^{12}$ Por seu turno, a Argentina também inicia projeto de rearmamento naval em contrato com empresas norte-americanas.

Outro fator irritante era o fato de que as exportações argentinas eram deslocadas do mercado brasileiro pelo tratamento tarifário diferenciado que beneficiava os Estados Unidos - contrapartida de sua condição de principal comprador de café. Por seu turno, as exportações do Brasil para a Argentina eram afetadas por medidas fitossanitárias. Essa "guerra de quarentenas" tinha outro alvo, além do comercial: a imprensa portenha veiculava matérias tendentes a prejudicar a imigração européia para o Brasil. ${ }^{13}$ Ao celebrar seu centenário, em 1910, a Argentina era o maior exportador mundial de trigo e o segundo de carne congelada e lá. A renda per capita era equivalente à de Alemanha, Bélgica ou Holanda, superior à de Espanha, Itália, Suíça e Áustria. As bases desse êxito, entretanto, eram extremamente frágeis: falta de poupança interna; produção, armazenamento e transporte dos produtos de exportação controlados por agentes externos; constantes déficits orçamentários e comerciais; e crescente dívida externa.

\section{A Primeira Guerra Mundial}

A Argentina sustentou posição neutra na Primeira Guerra Mundial, postura que não se alterou apesar da mudança de governo - que passou do Partido Conservador ao Radical (UCR), em 1916. Além do principismo da UCR, que defendia a igualdade entre Estados, o fator determinante foi a hegemonia classe proprietária, que pretendia manter os fluxos migratórios dos países em conflito e continuar exportando para os beligerantes.

A queda das importações não incentivou maior produção manufatureira, na medida em que a elite agropecuária impedia a

12 CERVO, Amado Luiz e BUENO, Clodoaldo. Op.cit., p. 152, 167, 175 e 176. RUSSELL, Roberto, e TOKATLIAN, Juan Gabriel. Op. cit., p. 22.

${ }^{13}$ CERVO, Amado Luiz e BUENO, Clodoaldo. Op .cit., p. 153. 
adoção de políticas de fomento à industrialização por substituição de importações.

No plano das relações com o Brasil, o esforço de distensão bilateral promovido por Sáenz Peña culminará com a firma, por seu sucessor, Victorino de la Plaza, em 1915, do Tratado de Cordial Inteligência Política e Arbitragem (Pacto do ABC). Por esse acordo, as partes se comprometiam a submeter eventuais controvérsias a uma comissão. Apesar de ter sido celebrado na Argentina como fim do isolamento político e superação das rivalidades entre as três potências regionais, o tratado não foi ratificado pelo Congresso desse país.

Hipólito Yrigoyen, primeiro presidente eleito pelo voto universal, secreto e obrigatório (1916-1922, reeleito em 1928), faz o radicalismo (UCR) deslocar os conservadores do poder, com uma plataforma política que representava os interesses dos setores médios urbanos, em constante crescimento. Yrigoyen objetada a tentativa de revitalização do ABC em 1921. A abertura democrática argentina não significou maior abertura em relação ao Brasil.

A crise de 1929 desferiu golpe quase mortal na Argentina agroexportadora, pondo fim à conjuntura externa favorável ao extraordinário processo de acumulação de riqueza. A mudança da tradicional postura livre-cambista do Reino Unido foi consagrada na Conferência de Ottawa, em 1932, quando Londres adota o sistema de "preferência imperial", que beneficia os domínios da Commonwealth e restringe importações dos países alheios ao bloco. A restrição das exportações, a suspensão dos fluxos de capitais e o colapso dos preços de commodities inviabilizaram a continuidade do esquema de prosperidade que sustentava o país.

A segunda gestão de Yrigoyen (1928-1930) é marcada pela crise econômica, que deteriora sua base política e fomenta a conspiração de direita. $\mathrm{O}$ nacionalismo antidemocrático se nutre de fontes ideológicas européias - fascismo, nazismo, franquismo - e exalta as tradições hispânicas e religiosas. Essa visão nutre, ainda, suspeitas de conspiração internacional contra a grandeza do país. Surge o revisionismo histórico, que reabilita Rosas em detrimento da historiografia oficial de perfil mitrista.

Yrigoyen é deposto pelo general José Félix Uriburu (1930-1932). Inicia-se a "década infame", período de deterioração política que contrasta 
com a exuberância cultural - o apogeu de Carlos Gardel. O general Agustín Justo (1932-1938) sucede a Uriburu. O conservadorismo, carente de estrutura partidária, promove a chamada "concordância" com o radicalismo "antipersonalista", logrando pôr na Vice-Presidência Julio A. Roca, filho do ex-presidente.

Caberá a este último negociar tema crucial para a economia: o polêmico pacto Roca-Runciman (1933). Trata-se de acordo celebrado com o ministro do Comércio britânico para assegurar a presença das exportações agropecuárias no mercado inglês por meio de quotas de importação de carne. Em troca, o essencial das licenças de importação ficavam em mãos de frigoríficos britânicos e norte-americanos, e os ingleses seriam beneficiados com recuperação de fundos bloqueados, tratamento privilegiado a empresas e isenções tarifárias.

A Argentina insistiu em permanecer atrelada a uma potência mundial em declínio - o Reino Unido ${ }^{14}$ - pois acreditavam que, cessados os efeitos da Grande Depressão, tudo voltaria à normalidade. A dirigência argentina não tinha clara a decadência da Europa, sobretudo da GrãBretanha, como centro econômico e financeiro do mundo, e a ascensão dos Estados Unidos aos status de potência mundial. Com isso, perde a chance de redefinir a estratégia de inserção mundial e de atualizar sua política econômica, incorporando valor agregado aos produtos primários e lançando a industrialização.

Apesar da fragilidade política (a "década infame") e econômica e das falhas de apreciação do contexto global, a gestão de Agustín Justo representa momento de importante aproximação com o Brasil - o que mostra que a relação bilateral segue curso à parte. Desanuviadas as tensões militares do início do século e da recusa de aprofundar o pacto $\mathrm{ABC}$, o presidente argentino visita o Brasil em 1933. Na ocasião, é assinado, por Brasil, Argentina, Chile, México, Paraguai e Uruguai o Tratado Antibélico de Não-Agressão e Conciliação. São assinados, ademais, convênios sobre comércio e navegação e sobre intercâmbio comercial e turístico. Pela primeira vez a agenda bilateral se diversifica.

\footnotetext{
${ }^{14}$ Roca imaginava, não dependência, mas interdependência, "de modo que as empresas britânicas fossem dependentes da prosperidade do país anfitrião para poder sobreviver”. LANATA, Jorge. Op. cit., tomo II, p. 55. "Cândido, não?", pergunta Lanata.
} 
Getúlio Vargas visita Buenos Aires em 1935. A viagem coincide com a mediação em torno do conflito entre Paraguai e Bolívia. Os chanceleres dos países mediterrâneos assinam com seus homólogos de Brasil e Argentina (além de outros garantes) Protocolo sobre o Conflito do Chaco. O protagonismo do chanceler argentino Saavedra Lamas lhe vale o Prêmio Nobel da Paz em 1936.

\section{A Segunda Guerra Mundial}

A neutralidade argentina na Segunda Guerra, seguida por governos conservadores e pelo Grupo de Oficiais Unidos (GOU), liderados pelo coronel Juan Domingo Perón, retoma posição adotada na Primeira Guerra e deixa o país isolado no continente. A sociedade estava muito dividida, e a postura neutra não refletia qualquer consenso. A neutralidade sugeria várias interpretações, conforme a inclinação ideológica ou econômica: pacifismo, não-ingerência, apoio subliminar ao Eixo ou interesse de comércio simultâneo com os beligerantes. Em 1943, o GOU derruba o presidente Castilho e reforça a neutralidade - que, na visão norte-americana, significava claro favorecimento do Eixo. Deterioram-se as relaçôes com os Estados Unidos, que vetam a venda de armas e bens de capital.

Nas Conferências Panamericanas de Panamá (1939) e Havana (1940), a Argentina se opõe à tese da ruptura automática com o Eixo, e luta para que a Conferência do Rio de Janeiro (1942) apenas "recomende" o rompimento de laços.

Em meio esses desencontros, surgem os primeiros impulsos de integração econômica, inscritos no acordo comercial negociado pelo chanceler Oswaldo Aranha com o ministro da Fazenda argentino Federico Pinedo, ainda no bojo da convergência inaugurada por Vargas e Justo. No entanto, tais impulsos não sobreviveriam à rivalidade e tensão bilateral em torno da Segunda Guerra. A Argentina interpreta o alinhamento do Brasil como forma de obter benefícios econômicos e estratégicos dos Estados Unidos, na linha da suspeita do desejo de representar os interesses de Washington na América do Sul.

O desenlace da guerra forçará a mudança da posição argentina. A Ata de Chapultepec permite que o país volte ao sistema interamericano e 
se qualifique como membro fundador das Nações Unidas. Em 1944, o presidente Pedro Ramírez rompe relações com a Alemanha e o Japão, e em 1945, o general Edelmiro Farrell declara guerra ao Eixo.

\section{O Peronismo e a "terceira posição"}

A eleição de Perón, em 1946, contou com o apoio dos segmentos progressistas do radicalismo e de outros partidos, grupos sindicais e Forças Armadas. O sentimento antiamericano foi levado ao extremo pelo envolvimento, na campanha, do embaixador norte-americano Spruille Braden. A militância clamava: "Braden ou Perón”.

A sociedade argentina passava por transformações estruturais, com acelerado crescimento da urbanização e industrialização - desde 1943, o setor secundário superou o primário na formação do PIB. Consolidavamse uma nova classe média, uma burguesia industrial e uma classe obreira em ascensão econômica, que buscavam acesso equivalente ao poder político monopolizado pelas classes altas.

Com o advento de Perón, esses segmentos "plebeus" foram alçados a classe dirigente. O pilar sindical do peronismo, organizado pela Confederação Geral do Trabalho (CGT), aliciava as forças progressistas, retirando-as da órbita dos partidos de esquerda e pregando a harmonia entre capital e trabalho.

O peronismo é um partido de massas extraordinariamente heterogêneo, marcado por dissensões internas: ex-radicais, sindicalistas, militares, empresários, burocratas, baixa classe média. A doutrina peronista, ideologicamente difusa, se baseia em três idéias-força: "justicialismo" social, independência econômica e soberania política síntese de postulados nacionalistas, socialistas e da doutrina social da Igreja. Com forte apelo populista, o movimento é invencível nas urnas. Apesar de força democrática, o peronismo teve seu lado autoritário e perseguiu intelectuais, juízes e jornalistas.

Eva Perón personaliza aspectos revolucionários do movimento com seu estilo maternal, mítico, intercessor e transgressor dos canais burocráticos e hierárquicos do acesso ao poder.

No início de seu governo, Perón estava convencido da iminente eclosão da Terceira Guerra Mundial entre Estados Unidos e União 
Soviética, o que determinou sua política econômica e sua diplomacia nos anos 40. Certo de que o novo conflito manteria desarticulada a economia mundial, a Argentina apostou na autarquia e no nacionaldesenvolvimentismo. Elaboram-se Planos Qüinqüenais (1947-1951 e 1952-1956) e se forma um empresariado industrial à sombra do apoio oficial. A presença do Estado alcança proporções inéditas. $\mathrm{O}$ "justicialismo" redistribui renda e garante conquistas trabalhistas para a classe operária. A prosperidade contrasta com a realidade européia do imediato pós-guerra. Perón e Evita contribuem para a segurança alimentar da Espanha franquista, marginalizada pelo Plano Marshal. ${ }^{15}$

Sem acreditar na liberalização e multilateralização da economia, a Argentina não adere aos acordos de Bretton Woods e investe em acordos comerciais bilaterais.

Na política externa, determinada pelo conflito Leste-Oeste, surge a tese da "terceira posição", precursora do Movimento Não-Alinhado. Trata-se, a rigor, de buscar a máxima autonomia dentro do Hemisfério Ocidental. A Argentina adota posições complexas: rejeita o alinhamento automático e o imperialismo, mas se mantém na órbita dos Estados Unidos, aderindo ao Tiar; retoma relaçôes com a URSS, mas rejeita o comunismo; abstém-se na votação da resolução Uniting for Peace, pela qual a Assembléia Geral da ONU decide sobre temas vetados pela URSS no Conselho de Segurança; aspira ao protagonismo latino-americano apoiado em uma retórica de solidariedade; e inaugura a política de recuperação das Malvinas e de soberania territorial na Antártida.

Puig vê na "terceira posição" um novo projeto nacional, que poderia ter substituído o projeto da Generación del Ochenta. ${ }^{16} \mathrm{O}$ centro de referência não é mais a Grã-Bretanha, mas os Estados Unidos, e as relaçōes com a potência dominante não assumem caráter dependente, mas autônomo (e heterodoxo).

Tokatlian e Russell afirmam o surgimento, nesse período, do paradigma "globalista", visto que a Argentina diversifica seus vínculos políticos e comerciais sem barreiras ideológicas. ${ }^{17}$ Esse paradigma implica

\footnotetext{
${ }^{15}$ A intransigência da Espanha e de suas empresas durante a crise argentina de 2001/2002 foi considerada atitude de ingratidão pela opinião pública argentina.

${ }^{16}$ PUIG, Juan Carlos. Op. cit., p. 138, 140 e 141.

${ }^{17}$ RUSSELL, Roberto, e TOKATLIAN, Juan Gabriel. Op. cit., p. 30 e 31.
} 
alto perfil em foros internacionais na defesa da paz, do desarmamento e da distensão bipolar, a rejeição de regimes de congelamento da distribuição de poder, o impulso à integração regional e a busca de reformas no sistema econômico e financeiro internacional.

$\mathrm{O}$ antiamericanismo foi revertido de forma pragmática no segundo mandato de Perón. Começam a fluir investimentos norte-americanos, e o Governo celebra acordo com a Standard Oil em 1955, que prevê a constituição de uma "Califórnia Argentina de Petróleo S.A.” O acordo exaltou os ânimos nacionalistas e contribuiu para o golpe militar.

Em relação ao Brasil, Perón adotou atitude positiva, favorável à integração, no âmbito da tentativa de reedição do ABC. Essa proposta desperta desconfianças do Brasil, que suspeita que o peronismo, como promotor da integração, visava na verdade ao proselitismo regional. ${ }^{18}$ Getúlio Vargas é em princípio simpático à iniciativa, mas finalmente decide não aderir ao novo ABC. Frustrado com a negativa, Perón acusa o Itamaraty de "instituição supergovernamental" apegada à "política imperial de zonas de influência”, por julgar a aproximação com a Argentina como ato inamistoso frente aos Estados Unidos. ${ }^{19}$

O movimento peronista apresenta três etapas em sua história inicial: a ascendente (1946-1952), com estabilidade política e prosperidade econômica, que permite redistribuição de rendas; a tensão do final do primeiro mandato, a morte de Evita e a reeleição de Perón (1952); e a crise político-econômica que leva ao golpe de 1955 .

Empresas norte-americanas se sentiram agredidas pelo nacionalismo antiliberal e se aproximaram da oligarquia. A tensão atinge níveis extremos - centenas de manifestantes são bombardeados na Praça de Maio pela aviação naval. O golpe militar Revolução Libertadora, força o exílio de

\footnotetext{
${ }^{18}$ A desconfiança foi motivada pela pretensão do GOU de estabelecer alianças com Paraguai, Bolívia, Chile e Uruguai para confrontar o Brasil. Essas suspeitas são desveladas no livro do embaixador Sérgio Correa da Costa Crônica de uma Guerra Secreta - Nazismo na América: a conexão argentina, que ressalta os planos de hegemonia platense na hipótese de vitória do nazismo.

${ }^{19}$ Matéria da Tribuna da Imprensa citada por STUART, Ana Maria. Op. cit., p. 31. RUSSELL, Roberto, e TOKATLIAN, Juan Gabriel. Op. cit., p. 36. As declarações de Perón são contundentes: "deve-se desmontar todo o sistema do Itamaraty e devem desaparecer essas excrescências imperiais que constituem, mais que nenhuma outra razão, os principais obstáculos para que Brasil entre em uma união verdadeira com a Argentina” Apud LANÚS, J. Archibaldo. De Chapultepec a Beagle. Política exterior argentina 1945-1980. Buenos Aires: Emecé, 1984.
} 
Perón e a proscrição do partido. Nas décadas seguintes, a polarização peronismo-antiperonismo será a tônica da dinâmica política.

\section{Militares e radicais}

Os governos militares de 1955 a 1958 foram períodos de expurgo político e intervenções. No plano externo, a preponderância do conservadorismo inaugurou o alinhamento com os Estados Unidos. Não será possível, entretanto, encontrar na nova potência sucedâneo funcional ao que foi Reino Unido durante a belle époque argentina.

Em 1956 a Argentina adere aos acordos de Bretton Woods, passando a ter acesso ao FMI, e substitui a política de acordos comerciais bilaterais pela participação no regime multilateral de comércio. Reabre-se a dependência a empréstimos internacionais, que servem para financiar a infra-estrutura e compensar desequilíbrios comerciais.

Proscrita a maior força político-eleitoral, o peronismo, o único partido em condições de comandar o país era a UCR. O radicalismo se cindiu em duas correntes - a UCR do Povo, liderada por Ricardo Balbín, e a UCR Intransigente, chefiada por Arturo Frondizi. A cisão foi motivada pela atitude em relação ao peronismo: enquanto Balbín rejeitava qualquer aproximação, Frondizi estava aberto a alianças. Este último foi eleito (1958-1962), mas sua legitimidade seria permanentemente questionada pelos militares e opositores, que não toleravam seus laços com Perón.

Frondizi é o JK argentino: o maior impulsor do desenvolvimentismo baseado na industrialização por substituição de importações para o mercado interno, na implantação de indústria pesada e de infra-estrutura e na exploração de recursos naturais (petróleo e gás). O capital estrangeiro é apresentado como fundamental, despertando reaçóes nacionalistas.

A política externa oscila entre teses latino-americanistas e ocidentalistas: a "Revolução Libertadora" inaugura a dependência em relação aos Estados Unidos, ao mesmo tempo mantém elementos da "autonomia heterodoxa”. Frondizi privilegia os Estados Unidos, mas não deixa de buscar melhoras nas relações com a América Latina (resiste ao isolamento de Cuba).

Com o Brasil, Frondizi mantém ativa diplomacia presidencial. Em 1958 encontra-se com o presidente Juscelino Kubitschek. Nesse ano, 
é criado o Grupo de Cooperação Industrial Brasil-Argentina, com o objetivo de estimular o intercâmbio de bens manufaturados. Em 1961, Jânio Quadros e Frondizi realizam o histórico encontro de Uruguaiana. $\mathrm{Na}$ ocasião, assinam o Convênio de Amizade e Consulta, pelo qual se estabelece sistema de troca de informações.

Do ângulo brasileiro, a aproximação com a Argentina era uma das diretrizes da Política Externa Independente do período Quadros - Goulart. Dessa vez, a resistência à maior concertação será argentina, por três motivos: a busca de aprimoramento das relaçôes com os Estados Unidos; questões estruturais como a precariedade das vias de comunicação, disparidades econômicas e pequena escala de produção; e sobretudo as dificuldades políticas internas de Frondizi (a direita nacionalista argentina vê com maus olhos a aproximação com o Brasil, acusado de "hegemonia").

\section{Momento: instabilidade conjuntural com predomínio da rivalidade (1962-1979)}

O "espírito de Uruguaiana" não sobrevive ao ciclo de regimes militares na Argentina e no Brasil. Ainda durante as presidências civis de Guido (1962-1963) e Arturo Illia (1963-1966), aprofunda-se o clima de convulsão política com hostilidades entre as próprias Forças Armadas.

A Argentina, dominada por setores de direita, aprofunda o alinhamento com os Estados Unidos: condena Cuba, envia navios para a quarentena estabelecida na questão dos mísseis e apoia a intervenção na República Dominicana. Apesar disso, o nacionalismo conserva elementos da "autonomia heterodoxa": Illia cancela contratos celebrados por Frondizi com companhias estrangeiras de petróleo.

Em 1964, a pedido de Buenos Aires, autoridades brasileiras impedem que Perón, que fazia escala no Rio de Janeiro, siga viagem para a Argentina.

\section{A ditadura militar de 1966-1973}

O golpe militar de 1966 teve apoio de setores ultranacionalistas, católicos integristas e dirigentes sindicais, no âmbito do "pacto sindicalmilitar”. Começa a onda de assassinatos políticos. 
A chamada "Revolução argentina" apresenta dois períodos: o do general Juan Carlos Onganía (1966-1970), marcado pela dependência em relação aos Estados Unidos e pelo isolamento regional, e o dos generais Roberto Levingston (1970-1971) e Alejandro Lanusse (1971-1973), que contemplam certa afirmação autonomista, com aproximação dos países latino-americanos e maior intercâmbio com o Leste Europeu.

\section{Héctor Cámpora e a volta de Perón}

Lanusse admite que a única opção de estabilização do país é o retorno de Perón, que ocorre em 1973. Nesse ano, Héctor Cámpora preside meses de transição sintetizados na fórmula Cámpora al gobierno, Perón al poder; finalmente, renuncia para dar lugar à nova eleição de Perón.

O peronismo retoma o projeto de "autonomia heterodoxa": a Argentina integra o Movimento Não-Alinhado e aprofunda laços com países afro-asiáticos, ao mesmo tempo em que mantém relações "normais" com os Estados Unidos. Perón deixa de lado a postura de conflito com o Brasil. Entretanto, sua morte, em 1974, reduz consideravelmente o ímpeto dessas diretrizes de política externa.

Sua sucessora, María Estela Martínez de Perón, se distancia das bases do peronismo e se apega à ultradireita de López Rega. No plano externo, volta à política de alinhamento com os Estados Unidos. As relações com o Brasil entram em estagnação. A situação, insustentável, leva ao golpe de 1976.

\section{A ditadura militar de 1976-1983}

O "Processo de Reorganização Nacional", ${ }^{20}$ como foi chamada a ditadura militar, foi proclamado em 1976 como solução aos conflitos de poder, à subversão e à corrupção, apelando às tradições e à segurança nacional. O Congresso foi dissolvido, e os juízes da Corte Suprema, depostos. Suspenderam-se atividades político-partidárias e sindicais e fecharam-se jornais. Aprofundou-se a "guerra suja" contra os alegados inimigos internos do país; líderes políticos foram presos, torturados e

${ }^{20}$ O "Processo" teve quatro presidentes: os generais Rafael Videla (1976-1981), Roberto Viola (1981), Leopoldo Galtieri (1981-1982) e Reynaldo Bignone (1982-1983). 
exterminados. A luta em prol dos direitos humanos tem o apoio da administração Carter e justifica o Prêmio Nobel da Paz concedido a Pérez Esquivel em 1980.

A política econômica foi dominada pelo ministro ultraliberal Martínez de Hoz, que aplicou as teses monetaristas da Escola de Chicago: abertura comercial e financeira, elevação das taxas de juros e sobrevalorização da moeda. Eram anos de plata dulce - a especulação financeira. A resultante era desastrosa: aumento da dívida externa, desindustrialização, desemprego.

No plano externo, o regime militar manteve algumas orientações do último governo de Perón: participação no Movimento Não-Alinhado, aprofundamento das relações comerciais com a URSS (com quem a Argentina iniciou importante cooperação nuclear), "autonomia heterodoxa” em relação aos Estados Unidos (temas nucleares e direitos humanos).

As relações com o Brasil alternam momentos de tensão e estagnação: problemas de interpretação do Tratado de Paz, Amizade, Comércio e Navegação (1856), interdição de túnel na fronteira com o Chile pelo qual passam caminhões com mercadorias brasileiras, retaliação do Brasil, que fecha fronteiras para caminhões argentinos. Se houve cooperação bilateral, ela se deu no âmbito da sinistra "Operação Condor".

A Argentina se inquieta com a força da industrialização no Brasil, que amplia o diferencial de poder regional. O "milagre brasileiro" contrasta com a instabilidade política e econômica argentina, acentuando sentimentos de rivalidade e desconfiança.

No caminho oposto, surgem no plano acadêmico (Hélio Jaguaribe, Celso Lafer, Félix Peña, Aldo Ferrer) reflexões baseadas na convergência de condiçōes de dependência periférica, que apontam para as possibilidades de desenvolvimento endógeno e integração.

A corrente liberal de Martínez de Hoz era apoiada pelos militares "blandos", ao passo que a linha dura, antiperonista e ultranacionalista, defendia um Estado intervencionista. O primeiro grupo alentou a solução pacífica dos problemas limítrofes da Argentina e as negociações com Brasil e Paraguai que conduziram ao Acordo Tripartite. Já os "falcóes" elevaram o nível das tensões com o Chile, quase levando o país à guerra em 1978, não fosse a intervenção do papa João Paulo II. 


\section{Momento: Construção da Estabilidade Estrutural pela Cooperação (1979-1987)}

\section{Itaipu e energia nuclear. Visitas presidenciais}

Em 1979, a relação Brasil-Argentina dá um salto qualitativo extraordinário, elevando de forma irreversível o patamar dos laços bilaterais. Ainda durante os regimes militares, os entendimentos alcançados em torno dos pontos de maior confrontação - Itaipu e programas nucleares - fortalecem a confiança e modificam para sempre a natureza dos laços entre os dois países: torna-se obsoleta a hipótese de conflito e se inaugura a fase de construção da estabilidade estrutural no relacionamento entre os dois países pela via da cooperação.

A crescente demanda energética gerada pela industrialização brasileira previa a utilização do potencial hidrelétrico de Itaipu, em empreendimento bilateral com o Paraguai. Em 1966, Brasil e Paraguai firmam a "Ata das Cataratas" e, em 1973, o Tratado de Itaipu. A Argentina reage, sustentando a obrigação de consulta ou informação prévia sobre a construção de represas em rios internacionais de curso sucessivo. De sua parte, o Brasil defende a tese da soberania nacional sobre os recursos naturais e aplica uma política de fato consumado.

Desde 1967, a Argentina aplica ao problema de Itaipu a estratégia de avançar pela via multilateral. Nessa perspectiva, obtém votações favoráveis, por ampla maioria, nos foros internacionais, e firma em 1969 o Tratado da Bacia do Prata. Perón ainda tenta deixar de lado o conflito e propõe a exploração simultânea dos recursos naturais da região. Mas a fragilidade política interna e principalmente o desaparecimento do líder argentino inviabilizam a coordenação com o Brasil.

A Argentina diversifica a estratégia, acrescentando negociações bilaterais ao esquema multilateral (Bacia do Prata): denuncia o acordo de Nova York celebrado com o Brasil em torno de Itaipu e lança os projetos de Corpus, Yacyretá e Salto Grande em entendimentos diretos com Paraguai e Uruguai.

As tensões são desanuviadas de forma definitiva em 1979, com a assinatura do Acordo Tripartite de Cooperação Técnico-Operativa pelos chanceleres de Brasil, Argentina e Paraguai, que compatibiliza os projetos de Itaipu e Corpus. 
No plano da energia nuclear, em 1980, durante a visita de Estado do presidente João Figueiredo, é assinado o Acordo de Cooperação para o Desenvolvimento e a Aplicação dos Usos Pacíficos da Energia Nuclear.

É muito significativo o fato de que a Argentina - que na época tinha como hipóteses de conflito Brasil, Chile e Reino Unido - tenha decidido aprimorar seus laços com o Brasil, na contramão das políticas adotadas com os dois últimos. É também fundamental o fato de que essa postura se afirma apesar do contexto extraordinariamente turbulento, tanto interno - crise da ditadura militar - quanto externo - desastre das Malvinas. Isso demonstra mais uma vez que os laços com o Brasil têm dinâmica própria, não-subordinada à sustentabilidade política interna nem ao contexto externo global. Os avanços do relacionamento bilateral dependem, antes, da visão estratégica dos governos, especialmente das chancelarias.

\section{Malvinas e fim da ditadura}

A Guerra das Malvinas (1982) constitui evento central da história argentina. Suas condicionantes de política interna são a aliança entre o general Galtieri e o Almirante Massera, que resultou na deposição do general Viola e aproximou Exército e Marinha, e a rápida deterioração da situação interna - que exigia, aos olhos dos militares, empreendimento contra inimigo externo que gerasse coesão no país, em nível pelo menos equivalente à da Copa de 1978 .

A tentativa de recuperação das ilhas revela outro elemento muitas vezes presente na política externa argentina, segundo analistas locais: a dificuldade de correta percepção do contexto internacional. Acreditavase que o Reino Unido não reagiria a tempo e com tanta força e que os Estados Unidos adotariam posição neutra, em virtude da autodesignação argentina (no ver da cúpula militar) como líder da luta anticomunista na América Latina, em especial na América Central.

Os Estados Unidos temiam que a invasão despertasse reação anticolonialista na América Latina e favorecesse a aproximação da URSS. A Argentina exportava $80 \%$ de sua produção de cereais para a URSS e não aderiu ao embargo cerealífero imposto pelos Estados Unidos: o governo militar, furiosamente anticomunista, era o principal sócio latinoamericano do regime soviético. 
Isso demonstra o peso dos interesses agroexportadores na definição da postura externa argentina, embora não seja suficiente para "determinar" o posicionamento global do país: para tanto, além dos laços comerciais, outros fatores e interesses incidem, como a identidade "civilizacional" e a dependência financeira (empréstimos, dívidas) e comercial (importações). Apesar da dependência comercial, prevalecia o anticomunismo visceral da junta militar.

O Brasil apoiou de forma inequívoca a reivindicação argentina, o que fortaleceu adicionalmente a confiança recíproca. Além disso, o país representou os interesses da Argentina em Londres de 1982 a 1989.

Após o fiasco militar, Galtieri é sucedido pelo general Reynaldo Bignone (1982-1983), que convoca eleições. Cresce o clamor pela elucidação dos crimes contra os direitos humanos, e as Madres de la Plaza de Mayo reclamam seus filhos desaparecidos.

\section{Alfonsín e a redemocratização}

A vitória de Raúl Alfonsín (1983-1989), da UCR, impôs ao peronismo a primeira derrota nas urnas. $\mathrm{O}$ presidente assume um país economicamente quebrado, politicamente humilhado e socialmente fraturado.

A Comissão Nacional sobre Desaparecimento de Pessoas (Conadep), presidida por Ernesto Sábato, publica o relatório Nunca Mais. Em 1985, foram condenados os comandantes das juntas militares - generais Videla e Viola e almirante Massera. Os processos contra as patentes inferiores foram sustados pelas leis de "obediência devida" e "ponto final". Em 1990, Menem absolve a todos com as "leis de perdão". Todas essas leis de impunidade serão derrogadas por Kirchner em 2004.

Houve sublevações militares em 1987, 1988 e 1990, rejeitadas pela sociedade civil - ao contrário da passividade com que se assistia aos levantamentos anteriores.

A redemocratização não assegurou equilíbrio econômico. Em 1985, o Plano Austral tentou corrigir o curso, impondo controle de preços, salários e câmbio, redução dos gastos do Estado e freio à emissão monetária. Seguem-se os Planos Austral II e Primavera, com o congelamento de preços, tarifas, salários e câmbio. $\mathrm{O}$ fracasso desses planos produziu hiperinflação, escalada do dólar, desemprego, recessão e desgaste político de Alfonsín. 
Sob a condução do chanceler Dante Caputo, a política exterior é marcada por um alto perfil nas Américas do Sul e Central e no Movimento Não-Alinhado. Busca-se prestígio e distanciamento de Reagan.

Com a redemocratização do Brasil, em 1985, registram-se avanços históricos na relação com a Argentina, lançando os fundamentos de uma "cultura de amizade e integração" e elevando ainda mais o patamar da relação bilateral, mais uma vez de forma irreversível. Os presidentes José Sarney e Raúl Alfonsín realizam encontro em Foz do Iguaçu, inauguram a ponte Tancredo Neves e assinam documentos fundacionais da nova etapa de construção da estabilidade estrutural: a Declaração de Iguaçu e a Declaração Conjunta sobre Política Nuclear, que sublinha a vocação pacífica dos projetos nucleares.

\section{Momento: Construção da Estabilidade Estrutural pela Integração (desde 1986)}

\section{O Tratado de Integração}

O método de construção da estabilidade do relacionamento Argentina-Brasil, que já era estrutural desde o fim dos governos militares, evoluirá da cooperação para a integração.

Em 1986 Alfonsín e Sarney assinam a Ata para a Integração Brasileiro-Argentina e criam a Comissão de Execução do Programa de Integração binacional. A partir de um enfoque gradualista e flexível, busca-se estender o processo de integração a outros países da América do Sul, a começar pelo Cone Sul.

A construção da confiança na área nuclear prossegue com as visitas dos presidentes de Brasil e Argentina aos centros atômicos dos dois países em 1987 e 1988. Em 1987, o Brasil obtém o domínio da tecnologia de enriquecimento de urânio e dá conhecimento prévio ao presidente Alfonsín.

Em 1989, dá-se um terceiro salto qualitativo na relação bilateral, com a assinatura do Tratado de Integração, Cooperação e Desenvolvimento - que estabelece prazo de dez anos para a conformação do espaço econômico comum.

Se, por um lado, o início da aproximação, em 1985, coincide com o Plano Austral, que fortaleceu a gestão Alfonsín, os novos avanços nas 
relações bilaterais caminham em paralelo à queda de popularidade e de governabilidade da Argentina, tal como ocorrido durante o regime militar. Mais uma vez, demonstra-se a autonomia da posição do Brasil na diplomacia argentina em relação às vicissitudes da política interna.

É curioso, também, o fato de que o início da integração ocorre em um contexto de reversão das preferências da opinião pública: se em 1985 os laços com a América Latina eram mais valorizados, em 1987 a Europa passa a ser preferida pelos argentinos. ${ }^{21}$ Nos primeiros anos do Mercosul, persistirá a preferência de aproximação com o mundo desenvolvido (especialmente com os Estados Unidos), e não com os vizinhos.

\section{Menem e a década neo-liberal}

Prometendo um salariazo, Menem foi o eleito em 1989. Uma vez no poder, entretanto, realizou uma virada ideológica em direção à ortodoxia monetária e à mudança das alianças sociais e econômicas, internas e externas, que historicamente haviam caracterizado o peronismo (o "giro neo-liberal" ${ }^{22}$. Menem se afastou do sindicalismo e se aproximou da elite liberal e do establishment financeiro internacional. $\mathrm{O}$ sucesso de sua primeira gestão (1989-1995) no plano da estabilização econômica lhe permitiu negociar com Alfonsín (Acordo de Olivos) a reforma constitucional de 1994 e sua reeleição para um segundo mandato (1995-1999).

Os acontecimentos internacionais (fim da Guerra Fria, hegemonia dos Estados Unidos) e a carga ideológica neo-liberal foram pontos de referência ineludíveis para a política externa e política econômica. Acreditando ter encontrado atalho para alçar a Argentina ao Primeiro Mundo, Menem optou por adotar as recomendações do Consenso de Washington e alinhar-se à superpotência vencedora da Guerra Fria. ${ }^{23}$

\footnotetext{
${ }^{21}$ Estudo feito por Mora y Araujo em 1992. Citado por RUSSELL, Roberto, e TOKATLIAN, Juan Gabriel. Op. cit., p. 50.

${ }_{22}$ Menem matizou o alcance dessa mudança ideológica apontando para o que fizera Perón nos anos 50, ao se aproximar dos interesses norte-americanos.

${ }^{23}$ Os ideólogos do período apontavam para o que a seu ver fizera o Brasil, alinhando-se aos EUA, e esperavam receber benefícios equivalentes aos que em sua opinião haviam sido "facilitados" ao vizinho.
} 
As reformas estruturais abrangeram redução do Estado, liberalização comercial e financeira, privatizaçōes (com a conseqüente desnacionalização), reforma fiscal, desregulamentação. Em 1991, o ministro Domingo Cavallo lança o plano de conversibilidade (currency board), que estabelece a paridade peso-dólar e logra reduzir a inflação. Enquanto esteve à frente da economia, Cavallo conseguiu controlar as contas públicas graças aos recursos provenientes das privatizações e do acesso ao crédito externo. A Argentina goza de prosperidade. Mas a partir de 1995 surgem turbulências; as crises mexicana, asiática e russa desaceleram a economia e as exportações, forçam aumento nas taxas de juros e comprometem a credibilidade das economias emergentes. A desvalorização do Real, em 1999, prejudica ainda mais a competitividade das exportações argentinas, agravando a balança de pagamentos.

A política externa de Menem buscou reverter a imagem de um país imprevisível, trazendo de volta a Argentina ao "posicionamento normal" de alianças tradicionais com o Ocidente, diferenciando-se da "heterodoxia" das décadas precedentes - marcadas pela confrontação com os Estados Unidos e pelo terceiro-mundismo. A diplomacia do chanceler Guido di Tella teve como eixo central o relacionamento privilegiado com os Estados Unidos ("relaçõos carnais") e, paralela ou subsidiariamente, o projeto de integração regional (Mercosul), com ênfase nas relações com o Brasil. Uma política externa "bifronte" ou "tripolar", segundo o ponto de vista que se quiser adotar.

As mudanças mais importantes foram: abandono da posição de confrontação com o Reino Unido herdado da guerra; abandono do Movimento Não-Alinhado; abandono do projeto missilístico Condor II, ratificação do Tratado de Tlatelolco e adesão ao TNP e ao MTCR (Missile Technology Control Regime); modificação do perfil de votações nas Nações Unidas; e busca de protagonismo nas missões de paz (Guerra do Golfo).

É significativo o fato de que Menem tenha conservado a herança alfonsinista de integração com o Brasil em meio a um quase total afastamento das outras diretrizes. Há que se sublinhar, entretanto, que essa manutenção sofreu mudança importante em sua motivação: não se trata mais da construção de poder em bloco e da valorização do ser regional, mas de uma lógica de equilíbrio de poder. A priorização 
simultânea do relacionamento com Estados Unidos e Brasil traz à tona sua natureza ambivalente e contraditória, obrigando a uma hierarquização das alianças que quase sempre deixará clara a opção norte-americana. ${ }^{24}$

$\mathrm{Na}$ visão menemista, de um lado, os laços com Washington seriam garantia de contenção dos "excessos" da política externa do Brasil - às vezes vista como anacrônica, revisionista e hegemônica, ao passo que a Argentina se vê como fator de estabilidade regional; de outro, os laços com Brasília serviriam tanto para o projeto de crescimento econômico quanto para melhorar a posição negociadora frente aos Estados Unidos.

Em 1990, os presidentes Menem e Collor assinam a "Ata de Buenos Aires", que prevê a conformação do espaço econômico comum em cinco anos, reduzindo para 1995 o prazo anterior (1998) previsto pelo Tratado de Integração de 1988. Sobre essa base será assentada a primeira fase do Mercosul.

O Tratado de Assunção, ato constitutivo do Mercosul, é assinado em 1991. Em 1994, o Protocolo de Ouro Preto estabelece a estrutura institucional do Mercosul e lhe confere personalidade jurídica internacional. Inicia-se a fase da União Aduaneira.

Prossegue a diretriz de construção de confiança na área nuclear: em 1990, os presidentes assinam a Declaração sobre Política Nuclear Comum, que aprova o Sistema Comum de Contabilidade e Controle e determina sejam abertos entendimentos com a Aiea. No ano seguinte, firma-se o Acordo Bilateral para Usos Exclusivamente Pacíficos da Energia Nuclear, que cria a Agência Brasileiro-Argentina de Contabilidade e Controle de Materiais Nucleares (Abacc). Em seguida, é assinado o Acordo Quadripartite (Brasil, Argentina, Abacc e Aiea). Ainda no mesmo ano, Brasil, Argentina e Chile firmam o Acordo para a Proibição Completa das Armas Químicas e Bacteriológicas (Compromisso de Mendoza). Em 1994, os três países ratificam o Tratado de Tlatelolco.

Em 1997, os presidentes Fernando Henrique Cardoso e Carlos Menem consagram, na Declaração do Rio de Janeiro, o conceito de Aliança Estratégica. $\mathrm{O}$ instrumento de execução dessa aliança é o Mecanismo Permanente de Consulta e Coordenação Bilateral em matéria

\footnotetext{
${ }^{24}$ Russell e Tokatlian discutem nova forma de relação triangular Brasil-Argentina-Estados Unidos, com ênfase na cooperação e na construção da "autonomia relacional". RUSSELL, Roberto, e TOKATLIAN, Juan Gabriel. Argentina, Brasil y EEUU. El desafio de una esfera de cooperación.
} 
de Defesa e Segurança Internacional, cuja primeira reunião ministerial se realiza no mesmo ano, em Itaipava.

A Argentina tentou sem sucesso ingressar na Otan em 1998, mas obteve status de "aliado extra-Otan" dos EUA. A iniciativa provocou curiosidade e desconfiança no Brasil. Ainda no período Menem, surgem divergências em torno da ampliação do Conselho de Segurança.

\section{De la Rúa e o colapso}

As denúncias de corrupção e a deterioração do quadro econômicosocial no segundo mandato de Menem levam o eleitorado a votar contra o peronismo em 1999. As eleições são vencidas pela Alianza UCR-Frepaso, com a fórmula Fernando de la Rúa / "Chacho" Álvarez.

A Alianza radicalismo-centro esquerda se mostra incapaz de administrar. Domingo Cavallo retorna ao Ministério da Economia em 2001 e recebe do Congresso "faculdades especiais ampliadas" para salvar a estabilidade: busca "blindagem" financeira, aumenta impostos, tenta alterar o perfil da dívida e anuncia o plano déficit zero.

$\mathrm{Na}$ área externa, a Alianza mantém as prioridades de Menem, especialmente o relacionamento privilegiado com os Estados Unidos combinado com o Mercosul. Cresce a desconfiança em relação a iniciativas de liderança do Brasil, como a Reunião de Presidentes da América do Sul (Brasília, 2000). A Argentina resiste ao conceito "sul-americano" e insiste na dimensão "latino-americana", que inclui o México.

As relações bilaterais são severamente afetadas pela desvalorização do real, em 1999. Cavallo faz campanha ostensiva contra os efeitos dessa medida, que considera propositadamente dirigida contra a Argentina. Questiona-se a conveniência de aprofundar laços com um país instável (naquele momento, o Brasil). Os Ministérios da Economia (Cavallo) e das Relações Exteriores (Giavarini) apontam para direções opostas no relacionamento com o Brasil.

Outros setores não são afetados pela deterioração das relações: defesa, nuclear (criação, em 2001, da Agência Brasileiro-Argentina de Aplicações da Energia Nuclear - Abaen), tecnologia espacial.

A deterioração social e a desordem econômica chegam a níveis insustentáveis e produzem saques e violentas manifestações. Sob a pressão dos "panelaços", Cavallo e De la Rúa renunciam, abrindo um período de 
acefalia de tirar o fôlego - cinco presidentes em duas semanas. Rodríguez Saá decreta o défault da dívida.

\section{Duhalde, Kirchner e a "refundação" da Argentina}

Em janeiro de 2002, Eduardo Duhalde assume a Presidência de um país desnorteado. Sua prioridade é reconstruir a governabilidade. Para tanto, modifica a base de apoio do governo, corrigindo a tendência de Menem - não mais aliança com o establishment econômico-financeiro, mas com o setor produtivo nacional e com o peronismo tradicional. Com esse propósito, põe fim à conversibilidade e adota a "pesificação assimétrica”. A deterioração social atinge níveis alarmantes: pela primeira vez na História, a Argentina conhece a fome e a proliferação da miséria.

A posse do ministro da Economia Roberto Lavagna, em 2002, representa um ponto de inflexão. O país toca o fundo do poço e começa a se recuperar. Inicia-se um processo de crescimento econômico que continua até hoje. O governo lança programa de subsídios sociais para conter o drama social.

A crise argentina frustrou os setores que acreditavam que o país seria ajudado pelo mundo rico, ao qual pensava haver ingressado. A atitude de Estados Unidos, Espanha e Itália, que se concentraram na defesa dos interesses suas empresas e investidores privados, acirrou na Argentina a "síndrome de irrelevância" e favoreceu internamente as forças que defendiam o aprofundamento das relações com o Brasil e o Mercosul.

O Brasil foi visto, sobretudo por Duhalde, como sócio fiel. Empresas deram mostra de visão estratégica e investiram numa Argentina em crise quando as de outros países se retiravam A vitória do presidente Lula foi claro sinal da sociedade brasileira de que desejava investir na relação bilateral e aprofundar a aliança estratégica e o Mercosul.

Nas eleiçóes de 2003, enfrentam-se propostas antagônicas para a Argentina, polarizadas nas candidaturas peronistas de Kirchner (centroesquerda) e Menem (centro-direita). Vitorioso após a desistência deste último, Kirchner consolida sua autoridade e popularidade, assegura a governabilidade e o crescimento do país, lançando as bases do processo de "refundação" econômica e ética da Argentina. No plano externo, luta pela "reinserção digna" do país. 
O presidente Lula, em Visita de Estado à Argentina em 2003, assina com o presidente Kirchner o Consenso de Buenos Aires. Em 2004, ambos voltam a se encontrar no Rio de Janeiro e assinam a Ata de Copacabana. Esses documentos sublinham a necessidade de fomentar um desenvolvimento econômico com eqüidade e reiteram a aliança estratégica.

Em 2004, os problemas comerciais, as medidas protecionistas anunciadas pelo presidente Kirchner às vésperas das Cúpulas do Mercosul e suas críticas feitas à atuação da Petrobras na Argentina afetam o relacionamento bilateral. Apesar dessas questôes setoriais, Brasil e Argentina mantêm alto nível de entendimento e coordenação, no âmbito do Mercosul, nas negociações dos acordos com os Estados Unidos (Alca) e a União Européia, bem como do regime global de comércio na OMC.

\section{Conclusão}

Dois paradigmas se confrontam na política externa argentina, correspondendo a dois projetos de país (1) o rivadaviano-albertiano da "Geração de Oitenta", liberal e agroexportadora; e (2) a "autonomia heterodoxa" peronista, desenvolvimentista e industrializante.

Esses paradigmas foram reeditados em contextos mundiais mais complexos. O primeiro foi adotado pelos regimes militares e pelo governo Menem; o segundo teve elementos assimilados pelos militares e por Alfonsín. Duhalde e, hoje, Kirchner buscam afirmar a atualidade dos postulados da autonomia heterodoxa.

Os dois paradigmas são compatíveis com o aprofundamento das relações com o Brasil. Claro está que o segundo favorece mais, em princípio, a coerência histórica da "estabilidade estrutural" e a construção conjunta de poder, ao passo que o primeiro tende a privilegiar a abertura comercial hemisférica (Alca) em detrimento da concertação bilateral e no Mercosul.

Por outro lado, o próprio modelo desenvolvimentista pode ser favorável ou não à integração: no primeiro caso, ressalta a importância da integração das cadeias produtivas com vistas ao mercado ampliado; no segundo, inspira atitudes protecionistas e autárquicas.

Não é novo o receio de que se instaure uma divisão de trabalho regional, na qual a Argentina seria provedora de bens primários, e o 
Brasil de bens manufaturados: o presidente Frondizi já manifestara essa a preocupação a Jânio Quadros em Uruguaiana. À medida que a Argentina perde poder em relação ao Brasil, desde os anos 50, cada vez mais teme ser considerado irrelevante. Nesse contexto, o desnível de poder produziu um "discurso da assimetria" que sempre busca compensaçóes (comerciais) e equações de equilíbrio de poder (político). Nesse último caso, historicamente mais antigo e relevante, "terceiros" países foram envolvidos para "reequilibrar" esse diferencial; esses "terceiros" foram (ou são) Grã-Bretanha, Uruguai, Paraguai, Bolívia, Chile, Estados Unidos e México.

Ora, não interessa ao Brasil, como sempre sublinha o Governo, que a Argentina se desindustrialize ou se enfraqueça economicamente. O Brasil precisa de um sócio estratégico fortalecido, com o qual possa construir poder internacional num contexto de integração. O que conta, aqui, é a lógica da construção de poder compartilhado (jogo de soma positiva), e não a de reequilíbrio e contenção (jogo de soma zero).

A construção da estabilidade como "coerência estrutural" ou fio condutor do relacionamento bilateral implica a adoção dessa lógica da construção de poder compartilhado e a combinação de elementos dos dois paradigmas da política externa argentina - liberalismo, desenvolvimentismo e busca de autonomia regional e mundial.

A intensificação dos laços sociais e culturais em todos os níveis permitirão "internalizar" uma cultura de amizade e construir a "sociedade estratégica”, suplantando os resquícios de rivalidade e equilíbrio de poder. Segundo pesquisa realizada por Mora y Araújo, ${ }^{25}$ há disposição extremamente favorável para tanto na sociedade argentina. As conclusões da sondagem de opinião são eloqüentes:

- o Brasil é o país com quem a Argentina mais deveria estreitar vínculos (36 \%), superando Europa, Estados Unidos e Ásia;

- Brasil e Espanha são os países que evocam sentimentos e atitudes mais positivas $(70 \%)$;

- a imagem do Brasil está mais ligada à de "grandes mercados" (ao lado dos EUA) que à de país latino-americano; e

${ }^{25}$ Ipsos Mora y Araujo. Argentina y el mundo. Una mirada sobre Brasil. Buenos Aires: setembro de 2004. 
- a preferência pelo Brasil é majoritária no espectro ideológico, da direita à esquerda.

Recebido em 15 de outubro de 2004 Aprovado em 21 de janeiro de 2005

\section{Referências Bibliográficas}

BANDEIRA, Moniz. Conflito e Integração na América do Sul. Brasil, Argentina e Estados Unidos. Da Tríplice Aliança ao Mercosul-1870-2003. Rio de Janeiro: Revan, 2004.

CERVO, Amado Luiz e BUENO, Clodoaldo. História da Politica Exterior do Brasil. São Paulo: Ática, 1992.

CISNEROS, Andrés (comp.). Politica exterior argentina 1989-1999. Historia de un éxito. Buenos Aires: CARI, 1998.

CISNEROS, Andrés e ESCUDÉ, Carlos. Historia general de las relaciones exteriores de la República Argentina. Buenos Aires: Cari-Gel, 1999.

FAUSTO, Boris, e DEVOTO, Fernando. Brasil e Argentina. Um ensaio de história comparada. São Paulo: Editora 34, 2004.

FLORIA, Carlos Alberto e BELSUNCE, César A. García. Historia de los argentinos. Buenos Aires: Larousse, 2004.

LANATA, Jorge. Argentinos. 2 tomos. Buenos Aires: Edições B, 2002.

LANÚS, J. Archibaldo. De Chapultepec a Beagle. Politica exterior argentina 1945-1980. Buenos Aires: Emecé, 1984.

PUIG, Juan Carlos (comp.). America Latina: politicas exteriores comparadas. Buenos Aires: Gel, 1984.

RUSSELL, Roberto, e TOKATLIAN, Juan Gabriel. El lugar de Brasil en la politica exterior argentina. Buenos Aires: Fondo de Cultura Económica, 2003.

. Argentina, Brasil y EEUU. El desafío de una esfera de cooperación. Agenda Internacional, Buenos Aires, setembro-novembro de 2004.

STUART, Ana Maria. Política externa e institucionalidade democrática na Argentina. Uma_trajetória de desencontros. Politica Externa, São Paulo, Paz e Terra, junho-agosto de 2001 

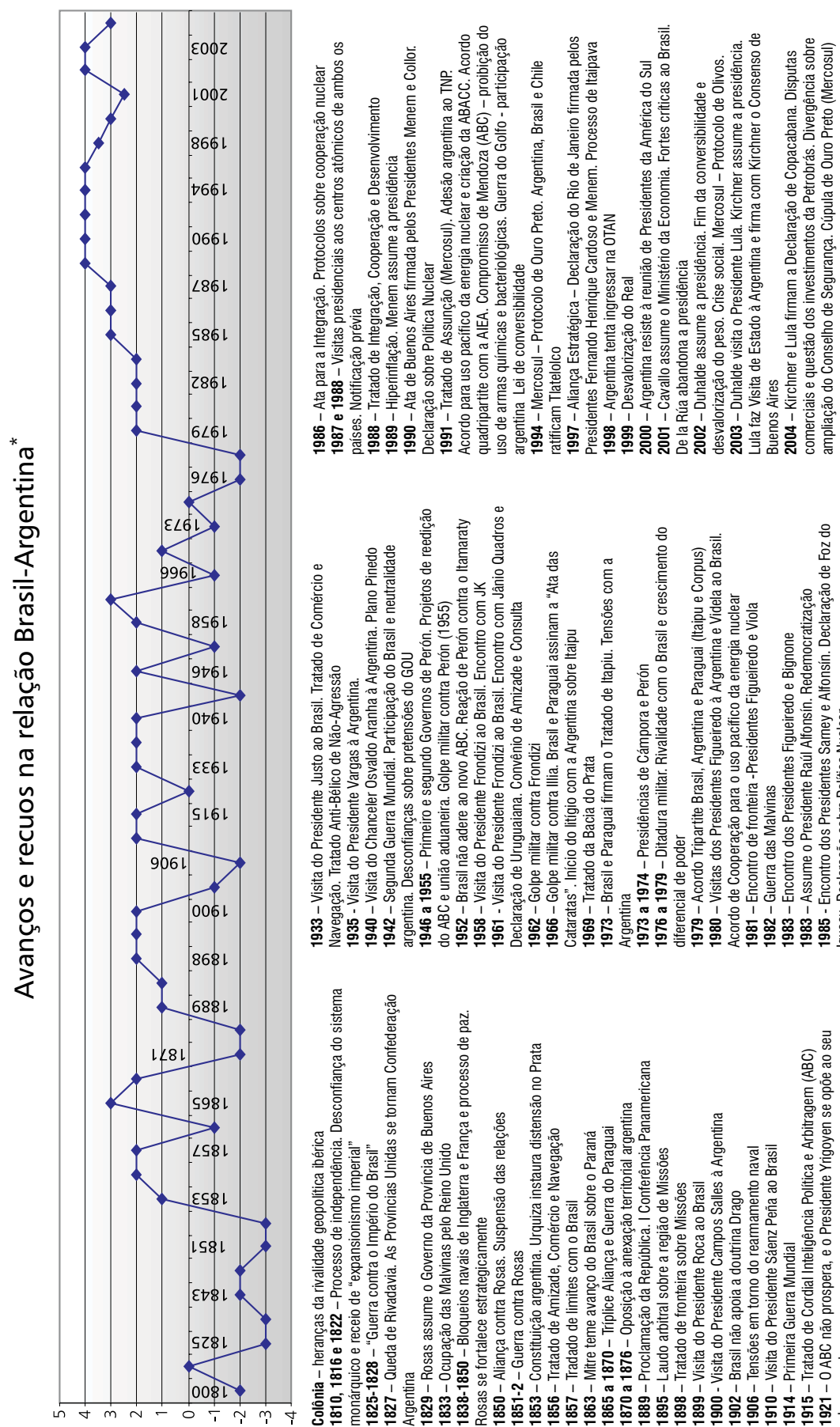

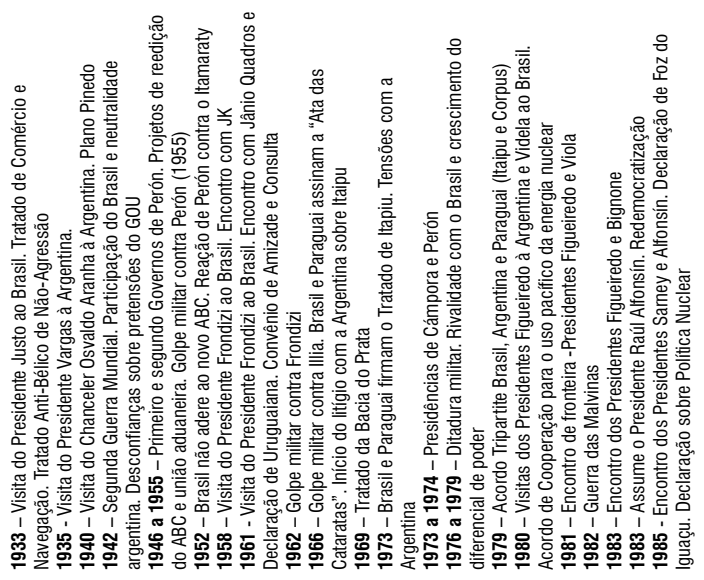

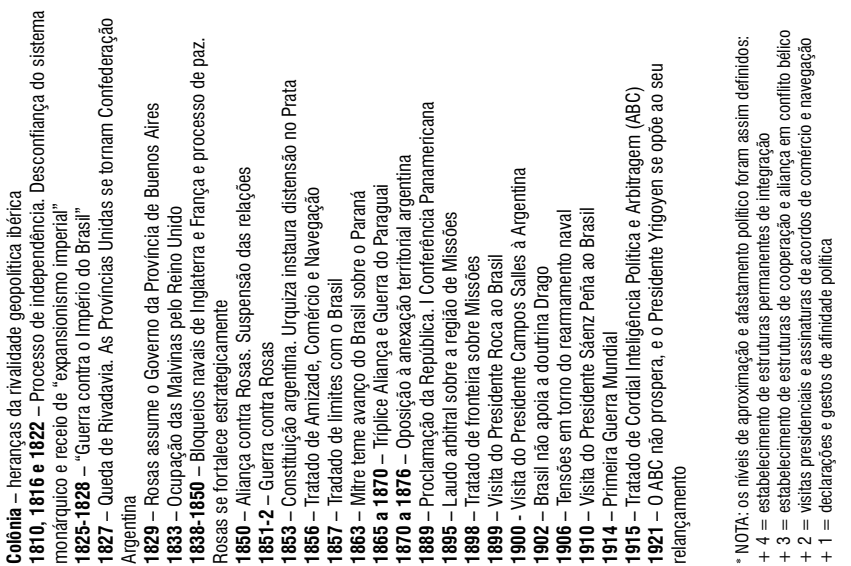




\section{Resumo}

No artigo se argumenta que as relações Brasil-Argentina, apesar de aparentemente erráticas, evoluem da instabilidade estrutural no século XIX à estabilidade estrutural pela integração no século XXI, passando por fases de rivalidade e cooperação conjuntural. A construção dessa estabilidade dá "coerência" ao relacionamento bilateral. A relação com o Brasil pertence a uma categoria relativamente autônoma, não-determinada pela política externa global da Argentina.

\section{Abstract}

The article argues that relations between Brazil and Argentina follow an apparently erratic path that leads from structural instability (XIX century) to structural stability with integration (XXI century). Intermediary phases are short-term rivalry and cooperation. Building this stability gives coherence to the bilateral relation. Ties with Brazil belong to a relatively autonomous field, not determined by the global foreign policies of Argentina.

Palavras-chave: Brasil, Argentina, Relações Bilaterais.

Key word: Brazil, Argentina, Bilateral Relations. 